\title{
Am I Ready? Competencies and Skill Sets Needed for Virtual Conference Hosts ${ }^{1}$
}

\author{
Lauri M. Baker and Matt Benge ${ }^{2}$
}

\section{Introduction}

This is the third publication in the Don't Fake It, Make It! Series about virtual conferences and meetings. Implementing a virtual conference or meeting can be a challenging task. Much is different when comparing virtual to face to face, such as the effects of teaching, audience motivators, and technology (Frisch \& Greene, 2020). Fifty-three percent of event planners say they don't have the necessary skills or experience to host an online event (Eventsforce, 2020). Whether hiring staff or recruiting colleagues to assemble a team, it is necessary to ensure your team is built based on the specific competency needs (Kozlowski \& Klein, 2000) for hosting a virtual conference or meeting.

\section{What is a team profile?}

Every member brings their individual competencies to a team; collectively, this is deemed the "team's profile" (Mathieu et al., 2014). In order to reach the expected outcomes of your virtual event, you need to ensure all the right pieces are present, and one of the most important pieces is the right team. Building a complete team, based on the identified needs of the team, is essential to the event's success. For instance, a football team can't win a game without a quarterback, nor can a baseball game be played without an umpire. Not only do the quarterback and umpire have specific roles in their respective sport, but they each bring specific competencies (skills) to help their games be successful. Building a complete team means planning out all the team roles (Beckhard, 1972) and required skills (Biddle, 1986) needed to complete the task(s).

\section{Competencies Needed for the Virtual Team's Profile}

All teams, whether virtual or face to face, should understand what everyone brings to the table. Leaders building a team should first identify the competencies needed for their team's success (the team profile). A competency is "a set of observable performance dimensions, including individual knowledge, skills, attitudes, and behaviors, as well as collective team, process, and organizational capabilities, that are linked to high performance, and provide the organization with sustainable competitive advantage" (Athey \& Orth, 1999 , p. 216). A complete virtual team profile means that each member adds competency-value to the overall team, thereby making it complete.

The virtual team profile consists of seven competency areas: (a) teaching instruction, (b) communication, (c) online technology, (d) program planning, (e) program design and implementation, (f) program evaluation, and ( $g$ ) event management. Each competency area describes skill sets needed to complete the virtual team profile (see Table 1).

1. This document is AEC728, one of a series of the Department of Agricultural Education and Communication, UF/IFAS Extension. Original publication date May 2021. Visit the EDIS website at https://edis.ifas.ufl.edu for the currently supported version of this publication.

2. Lauri M. Baker, associate professor, and Matt Benge, assistant professor, Department of Agricultural Education and Communication, UF/IFAS Extension, Gainesville, FL 32611.

The Institute of Food and Agricultural Sciences (IFAS) is an Equal Opportunity Institution authorized to provide research, educational information and other services

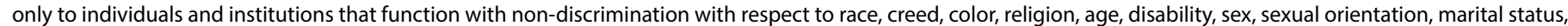

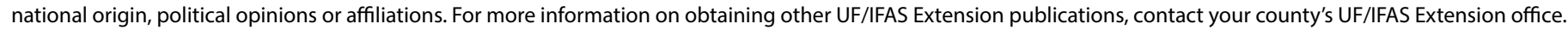
U.S. Department of Agriculture, UF/IFAS Extension Service, University of Florida, IFAS, Florida A \& M University Cooperative Extension Program, and Boards of County Commissioners Cooperating. Nick T. Place, dean for UF/IFAS Extension. 


\section{Final Considerations}

While you need someone skilled in every competency area in Table 1, this doesn't necessarily have to be seven different people. You may have people who can cover more than one competency area. When building your team, consider all of the skill sets needed before the event planning begins. You need time to build a cohesive team. Even if you have all worked together before, start by discussing competencies and skill sets and clarifying everyone's role. When everyone starts working on the event from this approach, everyone will be clear on their role in the later stages of the event process.

\section{Conclusion}

In summary, building a virtual team through the competency approach means you begin your planning with the skill sets of your team in mind. Your complete virtual event team profile will have all the necessary skill sets to reach your event objectives, keeping in mind that a team member may have more than one skill set. If you take the time to plan for all the competency areas, your event's objectives will have a high likelihood of success.

\section{References}

Athey, T. R., \& Orth, M. S. (1999). Emerging competency methods for the future. Human Resource Management, $38(3), 215-226$.

Beckhard, R. (1972). Optimizing team building effort. Journal of Contemporary Business, 1(3), 23-32.

Biddle, B. J. (1986). Recent developments in role theory. Annual Review of Sociology, 12(1), 67-92. https://doi. org/10.1146/annurev.so.12.080186.000435

Boone, E. J., Safrit, R. D., \& Jones, J. (2002). Developing programs in adult education: A conceptual programming model (2nd ed.). Waveland Press.

Eventsforce. (2020, June). 7 key skills for running successful virtual events. https://www.eventsforce.com/ blog/7-key-skills-for-running-successful-virtual-events

Frisch, B., \& Greene, C. (2020, March 5). What it takes to run a great virtual meeting. Harvard Business Review. https://hbr.org/2020/03/ what-it-takes-to-run-a-great-virtual-meeting

Harder, A. (2015). Priority competencies needed by UF/ IFAS Extension county faculty. WC236. Gainesville, FL:
University of Florida Institute of Food and Agricultural Sciences. https://edis.ifas.ufl.edu/wc236

Kozlowski, S. W. J., \& Klein, K. J. (2000). A multilevel approach to theory and research in organizations: Contextual, temporal, and emergent processes. In K. J. Klein \& S. W. J. Kozlowski (Eds.), Multilevel theory, research, and methods in organizations (pp. 3-90). Jossey-Bass.

Leal, A., Lawson, K. M., Telg, R. W., Rumble, J. N., Stedman, N. L. P., \& Treise, D. (2020) Technically speaking: Technical skills needed for agricultural communication baccalaureate graduates. Journal of Applied Communications, 104(3). https://doi.org/10.4148/1051-0834.2339

Mathieu, J. E., Tannenbaum, S. I., Donsbach, J. S., \& Alliger, G. M. (2014). A review and integration of team composition models: Moving toward a dynamic and temporal framework. Journal of Management, 40(1), 130-160. https:// doi.org/10.1177/0149206313503014

Ramirez, A. (2020). 6 unexpected roles you'll need on your virtual event team. AccelEvents. https://www.accelevents. com/virtual-event-team-roles/amp/

Seevers, B., Graham, D., Gamon, J., \& Conklin, N. (1997). Education through cooperative extension. Delmar Publications.

Stofer, K. (2018). Getting engaged: Program and event planning for clients with diverse abilities.EDIS, 2018(2). https:// doi.org/10.32473/edis-wc299-2018

Telg, R. W. (2018). Instructional methods for distance education. EDIS, 2012(5). https://edis.ifas.ufl.edu/wc026

\section{Appendix: Articles in This Series}

1. Don't Fake It, Make It! Thriving in Virtual Conferences and Meetings

2. Applying Learning Theory to Virtual Conference Spaces

3. Am I Ready? Competencies and Skill Sets Needed for Virtual Conference Hosts

4. Technology and Tools for Virtual Hosts

5. Let's Do This Right: Best Practices for Hosting Virtual Conferences

6. Host with the Most: Best Practices for Hosting Virtual Meetings 


\section{Best Practices for Hosting Virtual Webinars}

\section{Best Practices for Hosting Virtual Events and Fairs}

\section{Best Practices for Attending Virtual Events}

Table 1.The Virtual Team's Profile

\begin{tabular}{|l|l|}
\hline \multicolumn{1}{|c|}{ Competency Area } & \multicolumn{1}{c|}{ Competency Skill Sets } \\
\hline Teaching instruction & Instructional design, objective setting, measurement, teaching methods (Telg, 2018). \\
\hline Communication & $\begin{array}{l}\text { Verbal communication, written communication, concise and clear writing, developing aesthetically } \\
\text { pleasing design (Leal et al., 2020). }\end{array}$ \\
\hline Online technology & $\begin{array}{l}\text { Understanding of Americans with Disabilities Act (ADA) compliance, platform knowledge and } \\
\text { experience, social media monitoring experience, technical troubleshooting, audio, video, editing } \\
\text { (Stofer, 2018; Ramirez, 2020). }\end{array}$ \\
\hline Program planning & $\begin{array}{l}\text { Locating preexisting information, identifying needs, setting priorities and goals, identifying the } \\
\text { target audience (Boone et al., 2002; Seevers et al., 1997). }\end{array}$ \\
\hline Program evaluation & $\begin{array}{l}\text { Developing content, selecting a virtual delivery method, identifying resources and materials, creating } \\
\text { a timeline (Boone et al., 2002; Seevers et al., 1997). }\end{array}$ \\
\hline Event management & $\begin{array}{l}\text { Quantitative and qualitative data gathering techniques, creating an evaluation instrument, } \\
\text { monitoring virtual conference activities, analyzing and interpreting evaluation data, communicating } \\
\text { evaluation information to stakeholders (Harder, 2015; Seevers et al., 1997). }\end{array}$ \\
\hline $\begin{array}{l}\text { Responsiveness, proactivity, organization, speaker management, attention to detail (Eventsforce, } \\
\text { 2020; Frisch \& Greene, 2020; Ramirez, 2020). }\end{array}$ \\
\hline
\end{tabular}

